\title{
Activity and Durability of Ternary PtRuIr/C for Methanol Electro-oxidation
}

\author{
Dongsheng Geng, Daisuke Matsuki, Jiajia Wang, Tomoyuki Kawaguchi, \\ Wataru Sugimoto, ${ }^{*, z}$ and Yoshio Takasu*
}

Department of Fine Materials Engineering, Faculty of Textile Science and Technology, Shinshu University, Nagano 386-8567, Japan

Carbon supported $\mathrm{Pt}_{1} \mathrm{Ru}_{1} \mathrm{Ir}_{x}(0 \leqslant x \leqslant 2)$ nanoparticles were prepared by a coimpregnation reductive pyrolysis method and their electrocatalytic activity toward methanol electro-oxidation at 25,40 , and $60^{\circ} \mathrm{C}$ was investigated. The mass activity (current normalized by the mass of Pt) for methanol electro-oxidation increased as a function of Ir content and cell temperature. Despite the increase in methanol electro-oxidation activity, the addition of Ir does not affect the CO tolerance of the ternary electrocatalyst. The addition of Ir also enhances the durability of the catalyst. The enhancement in activity and durability is discussed based on CO stripping measurements and X-ray photoelectron spectroscopy analysis of the catalysts. (c) 2009 The Electrochemical Society. [DOI: 10.1149/1.3060111] All rights reserved.

Manuscript submitted August 18, 2008; revised manuscript received October 24, 2008. Published January 15, 2009.

The direct methanol fuel cell is widely considered as a potential highly efficient and clean energy source. Despite considerable advances in recent years, many technical barriers still need to be overcome in the development of electrocatalysts for the widespread commercialization. ${ }^{1}$ One of the major problems is the insufficient catalytic activity of the anode catalysts leading to slow kinetics of methanol electro-oxidation. The binary PtRu alloy is one of the most promising electrocatalysts for methanol electro-oxidation ${ }^{2,3}$ due to the ability of $\mathrm{Ru}$ in the alloy to promote fast oxidation of $\mathrm{CO}$. The promotional effect of $\mathrm{Ru}$ has mainly been discussed based on the so-called bifunctional mechanism ${ }^{4}$ or electronic effect ${ }^{5,6}$ or a mixture of both. ${ }^{7}$ It is generally accepted that the oxophilic ruthenium in the $\mathrm{Pt}-\mathrm{Ru}$ catalyst dissociates water into $\mathrm{OH}$ and $\mathrm{H}$ at lower potential than that on platinum. ${ }^{8,9}$ The $\mathrm{CO}$ chemisorbed on the platinum sites can then be oxidized by the neighboring $\mathrm{OH}$. In addition, the electronic structure of platinum can be modified by forming an alloy with $\mathrm{Ru}$, resulting in the weakening of $\mathrm{CO}$ adsorption on platinum. ${ }^{10,11}$

Despite the promising activity of the PtRu alloy, further improvement in activity and durability is necessary for practical application. The incorporation of a third metal, such as W, Mo, Co, Ni, Sn, Os, $\mathrm{Rh}, \mathrm{Pb}, \mathrm{Bi}$, Ir, etc., ${ }^{12-25}$ is a typical approach to develop methanol oxidizing catalysts with improved performance. Among the ternary alloy catalysts, the PtRuIr/C system seems to be promising; the promoting effect of Ir on the methanol electro-oxidation has been studied to some extent with limited composition and temperature range. ${ }^{18-25}$

In this work, we conducted a systematic study on the PtRuIr/C system by preparing a series of catalysts with various Ir content and studied their electrocatalytic methanol oxidation activity at different temperatures. In addition to the initial quasi-steady state activity, the durability of the ternary catalyst was studied.

\section{Experimental}

Carbon-supported PtRuIr electrocatalysts were prepared by an impregnation reductive pyrolysis method similar to previously described methods. ${ }^{26,27}$ In a typical procedure, carbon black (Vulcan XC-72R, $254 \mathrm{~m}^{2} \mathrm{~g}^{-1}$ ) was added to 1-butanol solutions of $\mathrm{H}_{2} \mathrm{PtCl}_{6} \cdot 6 \mathrm{H}_{2} \mathrm{O}, \mathrm{RuCl}_{3} \cdot n \mathrm{H}_{2} \mathrm{O}$, and $\mathrm{H}_{2} \mathrm{IrCl}_{6} \cdot n \mathrm{H}_{2} \mathrm{O}$. After thoroughly mixing the precursor solution, the solution was dried at $60^{\circ} \mathrm{C}$ to a powder state. The dried powder was then reduced in a tube furnace under flowing $\mathrm{H}_{2}(10 \%)+\mathrm{N}_{2}(90 \%)$ gas for $2 \mathrm{~h}$ at $200^{\circ} \mathrm{C}$. All catalysts were prepared so that the PtRu atomic ratio was Pt:Ru $=1: 1$ and the PtRu mass loading was PtRu:C = 30:70. The Ir

* Electrochemical Society Active Member

z E-mail: wsugi@shinshu-u.ac.jp atomic ratio in $\mathrm{Pt}_{1} \mathrm{Ru}_{1} \mathrm{Ir}_{x}$ was varied from $0 \leqslant x \leqslant 2$. The atomic ratio, mass percent, and metal loading are summarized in Table I.

The structure of the catalysts was characterized by X-ray diffraction [(XRD), Rigaku RINT-2550 with monochromated $\mathrm{Cu} \mathrm{K} \alpha$ radiation]. Wide-angle scan $\left(2 \theta=15-95^{\circ}\right)$ was recorded at a scan speed of $2^{\circ} \mathrm{min}^{-1}$. Detailed profiles near the face-centered cubic (fcc) (200) plane $\left(2 \theta=62-75^{\circ}\right)$ were collected with a step scan of $0.02^{\circ}$ and counting time of $5 \mathrm{~s}$. High-resolution scanning electron microscopy [(HRSEM), Hitachi S-5000] was used for morphological observation of the catalyst. The composition of the catalysts before and after electrochemical studies was analyzed by X-ray photoelectron spectroscopy (XPS). All spectra were referenced by setting the $\mathrm{C} 1 \mathrm{~s}$ peak to $285.2 \mathrm{eV}$.

An automatic polarization system (Hokuto Denko Corp. HSV100) and a three-compartment cell were employed for the electrochemical measurements with a Pt mesh as the counter electrode. All potentials were measured vs an $\mathrm{Ag} / \mathrm{AgCl}$ (saturated $\mathrm{KCl}$ ) electrode maintained at the same temperature as the working electrode. The following equation was considered for the temperature effect

$$
E \text { vs } \mathrm{Ag} / \mathrm{AgCl}(298)=E \text { vs } \mathrm{Ag} / \mathrm{AgCl}(T)+(T-298) \partial E / \partial T
$$

where $\partial E / \partial T=1.0049 \mathrm{mV} \mathrm{K}^{-1}$. All potentials in this study are reported with respect to the reversible hydrogen electrode scale $[\operatorname{RHE}(T)]$.

Catalyst ink was prepared by dispersing $20 \mathrm{mg}$ of the electrocatalysts in $10 \mathrm{~mL}$ of methanol and was subject to ultrasonification for $30 \mathrm{~min}$. Then, $20 \mu \mathrm{L}$ of the catalyst powder dispersion was dropped onto a glassy carbon surface with an exposed area of $0.196 \mathrm{~cm}^{2}$, giving metal coatings in the range of $60-100 \mu \mathrm{g} \mathrm{cm}^{-2}$, depending on the metal loading. After drying the droplet at $60^{\circ} \mathrm{C}$, $20 \mu \mathrm{L}$ of a $1 \mathrm{wt} \%$ Nafion alcoholic solution was further dropped on the electrode surface and heated again at $60^{\circ} \mathrm{C}$ to stabilize the electrocatalysts. The electrodes were first pretreated to remove surface contamination by cycling the electrode potential between 0.05 and $0.80 \mathrm{~V}$ vs RHE at $50 \mathrm{mV} \mathrm{s}^{-1}$ for 100 cycles in $0.5 \mathrm{M} \mathrm{H}_{2} \mathrm{SO}_{4}$. Although the minimum number of cycles necessary for the surface cleaning process may vary due to the different metal content in the samples, 100 cycles were enough to assure quasi-steady-state voltammograms for all of the catalysts irrespective of the sample composition and cell temperature. Electrocatalytic methanol oxidation was then measured by chronoamperometry in $1 \mathrm{M} \mathrm{CH} \mathrm{CH}_{3} \mathrm{OH}$ $+0.5 \mathrm{M} \mathrm{H}_{2} \mathrm{SO}_{4}$. The current recorded at $1800 \mathrm{~s}$ after stepping the potential to $0.50 \mathrm{~V}$ was used as the quasi-steady-state current. Electrochemical measurements were carried out at 25,40 , and $60^{\circ} \mathrm{C}$. CO-stripping voltammograms were accumulated by the electrooxidation of preadsorbed $\mathrm{CO}$ at $60^{\circ} \mathrm{C}$. $\mathrm{CO}$ was preadsorbed by bubbling $\mathrm{CO}$ gas through the electrolyte for 40 min followed by purging with nitrogen for $40 \mathrm{~min}$ to remove residual $\mathrm{CO}$ in the solution, while holding the electrode potential at $0.10 \mathrm{~V}$ vs RHE. The poten- 
Table I. The nominal composition of the prepared catalysts.

\begin{tabular}{|c|c|c|c|c|c|c|c|c|}
\hline \multirow[b]{2}{*}{ Sample } & \multicolumn{5}{|c|}{ Content (mass \%) } & \multicolumn{3}{|c|}{ Metal content (mol \%) } \\
\hline & $\mathrm{Pt}$ & $\mathrm{Ru}$ & Ir & Total metal & Carbon & $\mathrm{Pt}$ & $\mathrm{Ru}$ & Ir \\
\hline $\mathrm{Pt}_{1} \mathrm{Ru}_{1} / \mathrm{C}$ & 19.8 & 10.2 & 0 & 30.0 & 70.0 & 50.0 & 50.0 & 0 \\
\hline $\mathrm{Pt}_{1} \mathrm{Ru}_{1} \mathrm{Ir}_{1 / 2} / \mathrm{C}$ & 18.0 & 9.3 & 8.9 & 36.2 & 63.8 & 40.0 & 40.0 & 20.0 \\
\hline $\mathrm{Pt}_{1} \mathrm{Ru}_{1} \mathrm{Ir}_{3 / 4} / \mathrm{C}$ & 17.2 & 8.9 & 12.8 & 38.9 & 61.1 & 36.4 & 36.4 & 27.2 \\
\hline $\mathrm{Pt}_{1} \mathrm{Ru}_{1} \mathrm{Ir}_{1} / \mathrm{C}$ & 16.5 & 8.6 & 16.3 & 41.4 & 58.6 & 33.3 & 33.3 & 33.3 \\
\hline $\mathrm{Pt}_{1} \mathrm{Ru}_{1} \mathrm{Ir}_{3 / 2} / \mathrm{C}$ & 15.3 & 7.9 & 22.6 & 45.8 & 54.2 & 28.6 & 28.6 & 42.8 \\
\hline $\mathrm{Pt}_{1} \mathrm{Ru}_{1} \mathrm{Ir}_{2} / \mathrm{C}$ & 14.2 & 7.4 & 28.0 & 49.6 & 50.4 & 25.0 & 25.0 & 50.0 \\
\hline $\mathrm{Pt}_{1} \mathrm{Ir}_{1} / \mathrm{C}$ & 16.7 & 0 & 16.5 & 33.2 & 66.8 & 50.0 & 0 & 50.0 \\
\hline $\mathrm{Ir} / \mathrm{C}$ & 0 & 0 & 20.0 & 20.0 & 80.0 & 0 & 0 & 100 \\
\hline
\end{tabular}

Table II. The electrochemical active surface area (ECSA) of $\mathrm{Pt}_{1} \mathrm{Ru}_{1} \mathrm{Ir}_{x} / \mathrm{C}$ catalysts calculated from the CO electro-oxidation charge at $T$ $=60^{\circ} \mathrm{C}$.

\begin{tabular}{lccccc} 
Catalyst & $\mathrm{PtRu} / \mathrm{C}$ & $\mathrm{Pt}_{1} \mathrm{Ru}_{1} \mathrm{Ir}_{1 / 2} / \mathrm{C}$ & $\mathrm{Pt}_{1} \mathrm{Ru}_{1} \mathrm{Ir}_{3 / 4} / \mathrm{C}$ & $\mathrm{Pt}_{1} \mathrm{Ru}_{1} \mathrm{Ir}_{1} / \mathrm{C}$ & $\mathrm{Pt}_{1} \mathrm{Ru}_{1} \mathrm{Ir}_{3 / 2} / \mathrm{C}$ \\
\hline $\operatorname{ECSA}\left(\mathrm{m}^{2} \mathrm{~g}^{-1}\right)$ & 52 & 55 & 54 & 54
\end{tabular}
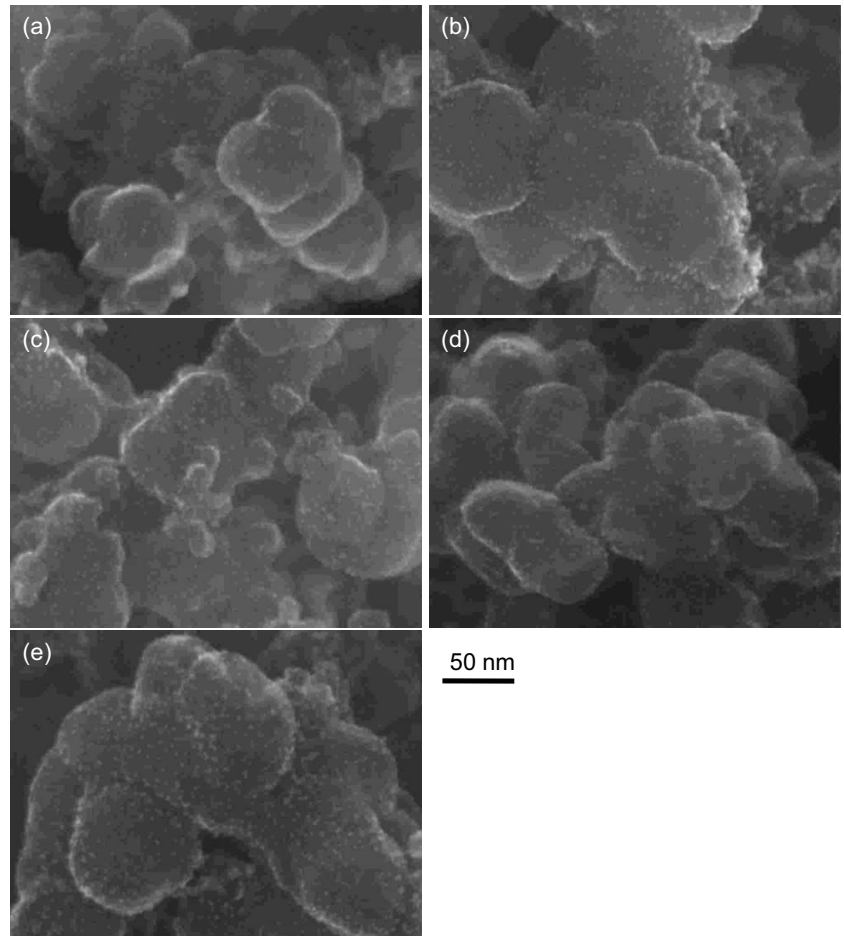

$50 \mathrm{~nm}$

Figure 1. HRSEM images of (a) $\mathrm{Pt}_{1} \mathrm{Ru}_{1} \mathrm{Ir}_{1 / 2} / \mathrm{C}$, (b) $\mathrm{Pt}_{1} \mathrm{Ru}_{1} \mathrm{Ir}_{3 / 4} / \mathrm{C}$, (c) $\mathrm{Pt}_{1} \mathrm{Ru}_{1} \mathrm{Ir}_{1} / \mathrm{C}$, (d) $\mathrm{Pt}_{1} \mathrm{Ru}_{1} \mathrm{Ir}_{3 / 2} / \mathrm{C}$, and (e) $\mathrm{Pt}_{1} \mathrm{Ru}_{1} \mathrm{Ir}_{2} / \mathrm{C}$.
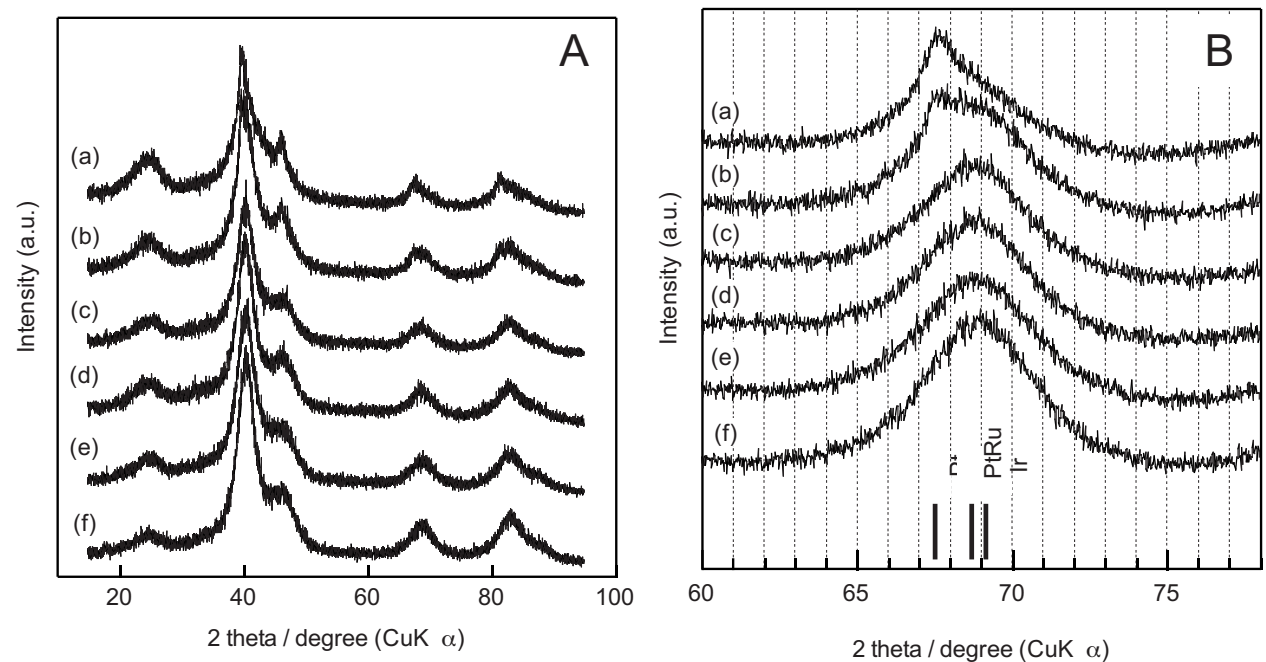

Figure 2. XRD patterns of $\mathrm{Pt}_{1} \mathrm{Ru}_{1} \mathrm{Ir}_{x} / \mathrm{C}$ catalysts. (A) Wide-angle profile and (B) detailed measurements near the fcc 220 peak: (a) $\mathrm{Pt}_{1} \mathrm{Ru}_{1} / \mathrm{C}$, (b) $\mathrm{Pt}_{1} \mathrm{Ru}_{1} \mathrm{Ir}_{1 / 2} / \mathrm{C}$, (c) $\mathrm{Pt}_{1} \mathrm{Ru}_{1} \mathrm{Ir}_{3 / 4} / \mathrm{C}$, (d) $\mathrm{Pt}_{1} \mathrm{Ru}_{1} \mathrm{Ir}_{1} / \mathrm{C}$, (e) $\mathrm{Pt}_{1} \mathrm{Ru}_{1} \mathrm{Ir}_{3 / 2} / \mathrm{C}$, and (f) $\mathrm{Pt}_{1} \mathrm{Ru}_{1} \mathrm{Ir}_{2} / \mathrm{C}$. 

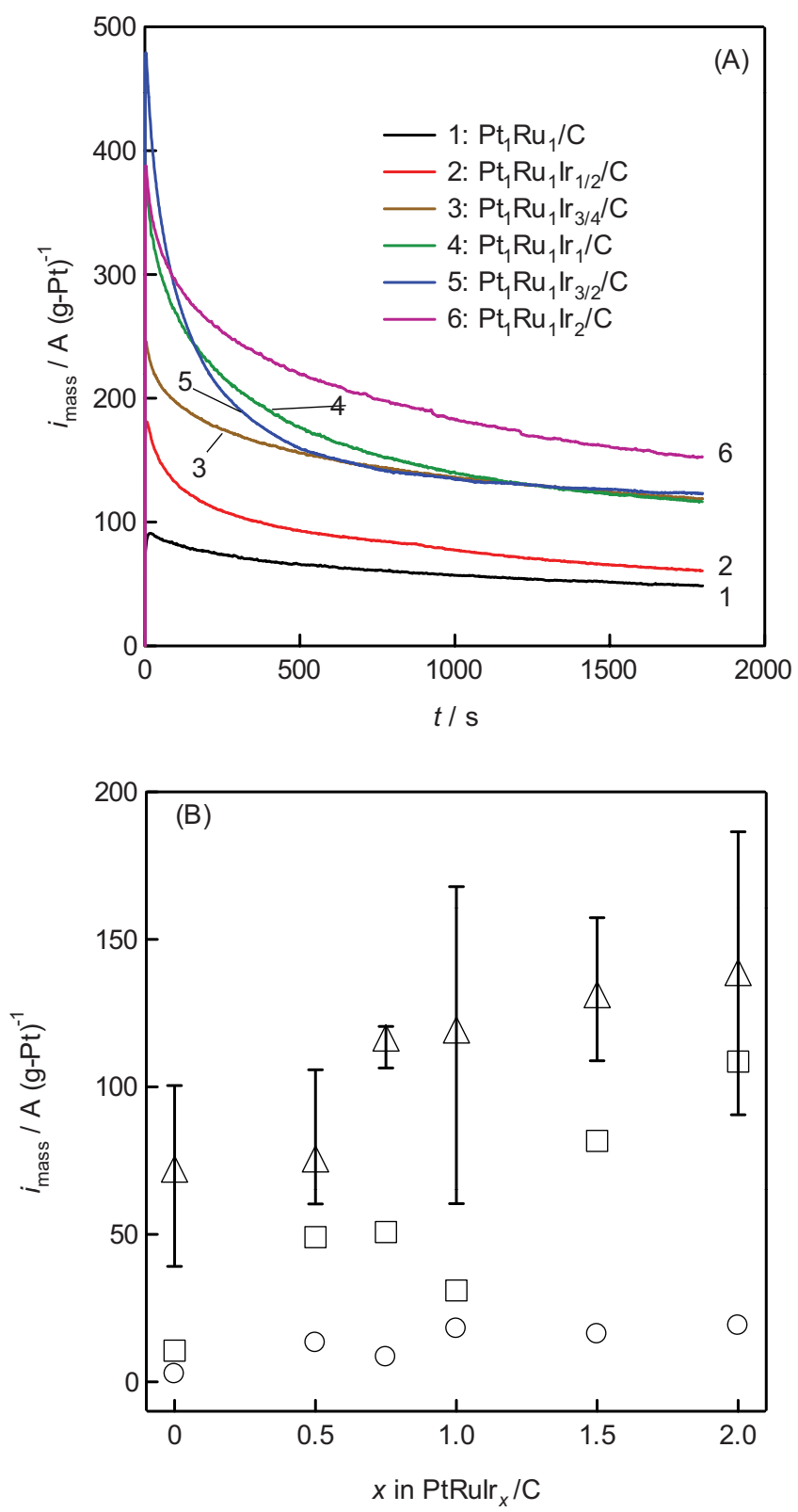

Figure 3. (Color online) (A) Typical chronoamperograms of the $\mathrm{Pt}_{1} \mathrm{Ru}_{1} \mathrm{Ir}_{x} / \mathrm{C}$ catalysts in $1 \mathrm{M} \mathrm{CH}_{3} \mathrm{OH}+0.5 \mathrm{M} \mathrm{H}_{2} \mathrm{SO}_{4}\left(60^{\circ} \mathrm{C}\right)$ at $0.50 \mathrm{~V}$ vs RHE. (B) The current density per unit mass of $\mathrm{Pt}_{2}$ in $\mathrm{Pt}_{1} \mathrm{Ru}_{1} \mathrm{Ir}_{x} / \mathrm{C}$ measured after $30 \mathrm{~min}$ at $0.50 \mathrm{~V}$ vs RHE in $1 \mathrm{M} \mathrm{CH}_{3} \mathrm{OH}+0.5 \mathrm{M} \mathrm{H}_{2} \mathrm{SO}_{4}$ at different temperatures. Circles: $25^{\circ} \mathrm{C}$, squares $40^{\circ} \mathrm{C}$, and triangles $60^{\circ} \mathrm{C}$.

contraction of the fcc lattice from $a=0.3926 \mathrm{~nm}$ for $\mathrm{Pt}$ to $0.3884 \mathrm{~nm}$ for $\mathrm{Pt}_{1} \mathrm{Ir}_{1}{ }^{29}$ Because the $a$ lattice parameter of $\mathrm{Pt}_{1} \mathrm{Ru}_{1}$ $\left(a=0.3881 \mathrm{~nm}^{30}\right)$ is very close to that of $\mathrm{Pt}_{1} \mathrm{Ir}_{1}$, the miscibility of $\mathrm{Ru}$ into the fcc PtIr alloy can be presumed to be less demanding compared to hexagonal close-packed (hcp) Ru incorporation into pure Pt. Another point is that the addition of Ir leads to an increase in the overall content of the fcc metal within the alloy. This should in turn facilitate incorporation of hcp Ru into the fcc lattice.

Typical chronoamerograms showing the current transients for PtRuIr/C in $1 \mathrm{M} \mathrm{CH}_{3} \mathrm{OH}+0.5 \mathrm{M} \mathrm{H}_{2} \mathrm{SO}_{4}$ are shown in Fig. $3 \mathrm{~A}$. The mass activity (methanol electro-oxidation current normalized per unit mass of Pt) measured at $0.50 \mathrm{~V}$ vs RHE at different temperatures $\left(25,40,60^{\circ} \mathrm{C}\right)$ are shown in Fig. 3. Increasing the temperature increases the mass activity regardless of the catalyst composition as expected according to improved kinetics. When one

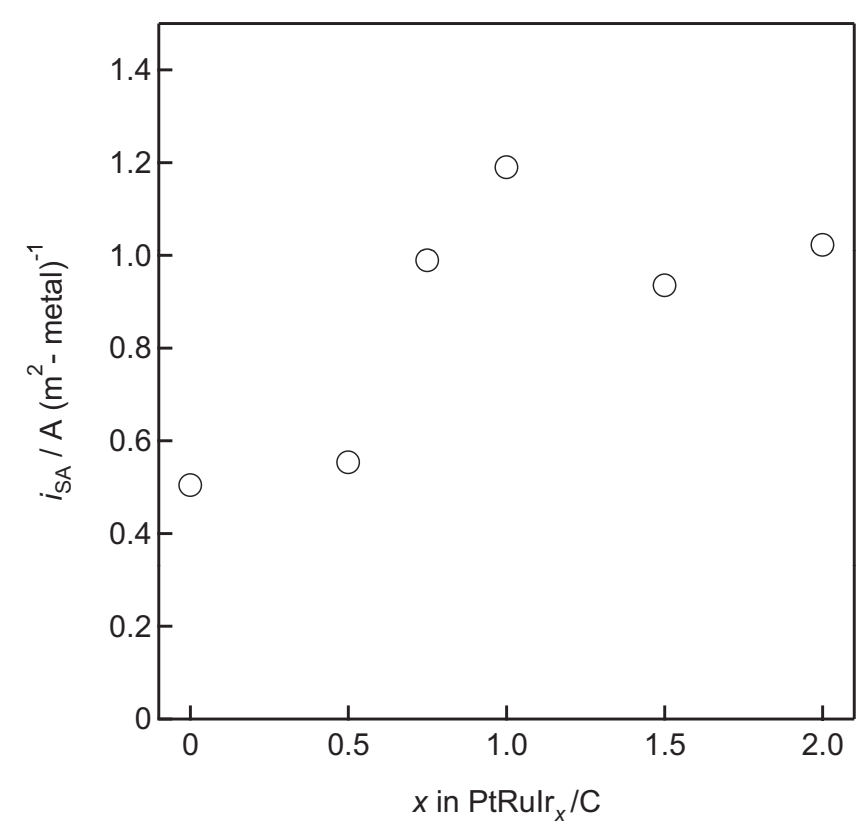

Figure 4. Current density per unit metal surface area for $\mathrm{Pt}_{1} \mathrm{Ru}_{1} \mathrm{Ir}_{x} / \mathrm{C}$ measured after $30 \mathrm{~min}$ at $0.50 \mathrm{~V}$ vs RHE in $0.5 \mathrm{M} \mathrm{H}_{2} \mathrm{SO}_{4}+1 \mathrm{M} \mathrm{CH}_{3} \mathrm{OH}$ $\left(60^{\circ} \mathrm{C}\right)$.

compares the mass activity as a function of the Ir content at a fixed temperature, a monotonous increase is observed with increasing Ir, clearly indicating that the addition of Ir promotes the Pt activity. As shown in Fig. 4, the specific activity (methanol electro-oxidation current normalized to the exposed metal surface area calculated from the $\mathrm{CO}$ oxidation charge) at $60^{\circ} \mathrm{C}$ increases with the increase of Ir content. Thus, it can be concluded that the addition of Ir provides an intrinsic enhancement in the catalytic activity. It is known that the mass loading influences the mass activity in the case of $\mathrm{PtRu} / \mathrm{C}$, showing maximum mass activity for 40 mass $\%$ $\mathrm{Pt}_{1} \mathrm{Ru}_{1} / \mathrm{C}{ }^{31}$ The trend in the mass activity with increasing Ir content resembles the mass activity dependence of $\mathrm{Pt}_{1} \mathrm{Ru}_{1} / \mathrm{C}$ with similar metal loadings. Thus, the promoting effect of Ir may be attributed in part to a perfection of the particle size.

To gain more insight into the promoting effect of Ir on the activity of the catalyst, $\mathrm{CO}$ stripping voltammetry was conducted (Fig. 5). The onset potential of the $\mathrm{CO}_{\mathrm{ad}}$ electro-oxidation for $\mathrm{Ir} / \mathrm{C}$ is comparable to $\mathrm{Pt} / \mathrm{C}$, indicating that $\mathrm{Ir}$ alone is a poor $\mathrm{CO}$ oxidizing catalyst. Thus, it is quite natural that the ternary $\mathrm{Pt}_{1} \mathrm{Ru}_{1} \mathrm{Ir}_{x} / \mathrm{C}$ catalysts show comparable or slightly poorer $\mathrm{CO}$ electro-oxidation activity as compared to $\mathrm{Pt}_{1} \mathrm{Ru}_{1} / \mathrm{C}$. The addition of $\mathrm{Ir}$ is evidently disadvantageous for $\mathrm{CO}$ electro-oxidation. It should be pointed out that the present results are not consistent with previous literature reports. Liang et al. ${ }^{19}$ and Sivakumar and Tricoli ${ }^{21}$ reported a negative shift in the onset potential of $\mathrm{CO}$ electro-oxidation for PtRuIr/C compared to the $\mathrm{PtRu} / \mathrm{C}$ catalyst. We believe the difference in the activity of the control sample $\left(\mathrm{Pt}_{1} \mathrm{Ru}_{1} / \mathrm{C}\right.$ catalyst $)$ is responsible for this apparent inconsistency.

The results obtained in this work reveal that the addition of Ir to PtRu markedly enhances the electrocatalytic methanol oxidation activity even though the addition of Ir does not promote $\mathrm{CO}$ oxidation, and Ir alone is a poor methanol electro-oxidation catalyst. It is known that $\mathrm{CO}$ is an intermediate in the process of methanol electro-oxidation. The electro-oxidation of methanol at a Pt-M alloy electrode is a multistep reaction ${ }^{32}$

$$
\begin{gathered}
\mathrm{Pt}+\mathrm{CH}_{3} \mathrm{OH} \rightarrow \mathrm{Pt}-\left(\mathrm{CH}_{3} \mathrm{OH}\right)_{\mathrm{ad}} \\
\mathrm{Pt}-\left(\mathrm{CH}_{3} \mathrm{OH}\right)_{\mathrm{ad}} \rightarrow \mathrm{Pt}-\left(\mathrm{CH}_{3} \mathrm{O}\right)_{\mathrm{ad}}+\mathrm{H}^{+}+\mathrm{e}^{-}
\end{gathered}
$$




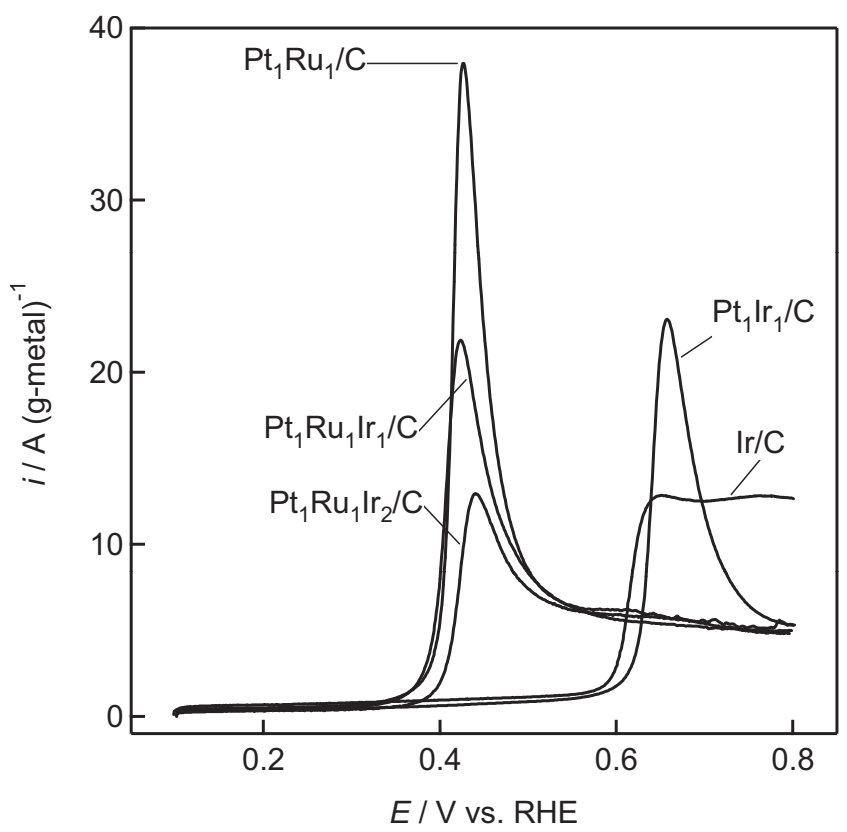

Figure 5. CO-stripping voltammograms in $0.5 \mathrm{M} \mathrm{H}_{2} \mathrm{SO}_{4}$ at $60^{\circ} \mathrm{C}(v$ $\left.=10 \mathrm{mV} \mathrm{s}^{-1}\right)$.

$$
\begin{gathered}
\mathrm{Pt}-\left(\mathrm{CH}_{3} \mathrm{O}\right)_{\mathrm{ad}} \rightarrow \mathrm{Pt}-\left(\mathrm{CH}_{2} \mathrm{O}\right)_{\mathrm{ad}}+\mathrm{H}^{+}+\mathrm{e}^{-} \\
\mathrm{Pt}-\left(\mathrm{CH}_{2} \mathrm{O}\right)_{\mathrm{ad}} \rightarrow \mathrm{Pt}-(\mathrm{CHO})_{\mathrm{ad}}+\mathrm{H}^{+}+\mathrm{e}^{-} \\
\mathrm{Pt}-(\mathrm{CHO})_{\mathrm{ad}} \rightarrow \mathrm{Pt}-(\mathrm{CO})_{\mathrm{ad}}+\mathrm{H}^{+}+\mathrm{e}^{-} \\
\mathrm{M}+\mathrm{H}_{2} \mathrm{O} \rightarrow \mathrm{M}-\left(\mathrm{H}_{2} \mathrm{O}\right)_{\mathrm{ad}}
\end{gathered}
$$$$
\mathrm{Pt}-(\mathrm{CO})_{\mathrm{ad}}+\mathrm{M}-\left(\mathrm{H}_{2} \mathrm{O}\right)_{\mathrm{ad}} \rightarrow \mathrm{Pt}+\mathrm{M}+\mathrm{CO}_{2}+2 \mathrm{H}^{+}+2 \mathrm{e}^{-}
$$

Here, $\mathrm{M}$ represents an alloying component or promoter metal. Most studies in this area have considered Reactions 6 and 7 as the rate-

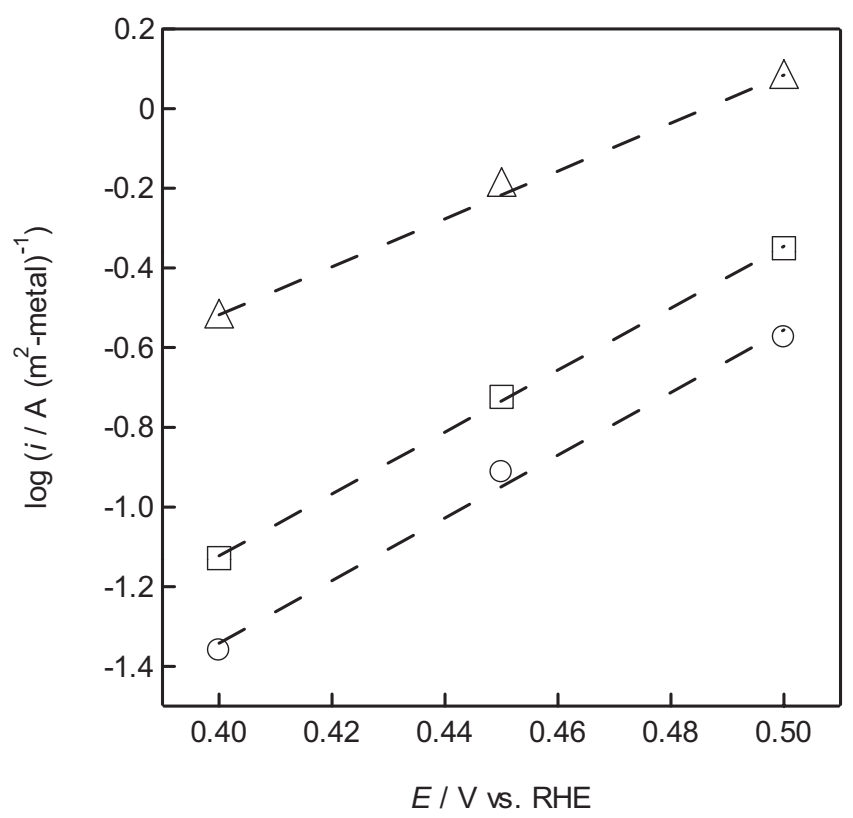

\begin{tabular}{|c|c|c|}
\hline \multirow[b]{2}{*}{ Number of cycles } & \multicolumn{2}{|c|}{ Mass activity $\left[\mathrm{A}(\mathrm{g} \mathrm{Pt})^{-1}\right]$} \\
\hline & $\mathrm{Pt}_{1} \mathrm{Ru}_{1} / \mathrm{C}$ & $\mathrm{Pt}_{1} \mathrm{Ru}_{1} \mathrm{Ir}_{2} / \mathrm{C}$ \\
\hline Initial $^{\mathrm{a}}$ & 134 & 193 \\
\hline $500^{\mathrm{b}}$ & 100 & 170 \\
\hline 1000 & 50 & 115 \\
\hline 2000 & 26 & 80 \\
\hline
\end{tabular}

Figure 6. Tafel plots for methanol electro-oxidation on $\mathrm{Pt}_{1} \mathrm{Ru}_{1} \mathrm{Ir}_{1} / \mathrm{C}$. Data obtained from the potentiostatic current decays in $0.5 \mathrm{M} \mathrm{H}_{2} \mathrm{SO}_{4}+1 \mathrm{M}$ $\mathrm{CH}_{3} \mathrm{OH}$ after $1800 \mathrm{~s}$. Circles: $25^{\circ} \mathrm{C}$, squares $40^{\circ} \mathrm{C}$, and triangles $60^{\circ} \mathrm{C}$.
${ }^{a}$ After the 100 surface cleaning cycles.

${ }^{\mathrm{b}}$ Numbers include the initial 100 cycles.

determining steps (rds) under different conditions and have ascribed the higher catalytic activity of Pt-M to oxophilic additives (M) accelerating the rates of Reactions 6 and $7 .^{25}$ However, our results demonstrate that $\mathrm{Pt}_{1} \mathrm{Ru}_{1} \mathrm{Ir}_{1} / \mathrm{C}$ and $\mathrm{Pt}_{1} \mathrm{Ru}_{1} \mathrm{Ir}_{2} / \mathrm{C}$ catalysts have lower $\mathrm{CO}$ oxidation activity compared to $\mathrm{Pt}_{1} \mathrm{Ru}_{1} / \mathrm{C}$. Thus, we believe that the addition of Ir cannot accelerate the rates of Reactions 6 and 7. Eliminating the above factor, we must turn to consider the earlier steps (Reactions 1-5) in the reaction mechanism. The only possibility is that the rds of methanol electro-oxidation reaction has been changed. ${ }^{33-37}$ Thus, Reaction 1-5 are the rate-determining steps, and the role of Ir is to accelerate these processes. Reactions 1-5 involve the adsorption and dehydrogenation of methanol. The addition of Ir appears to promote methanol adsorption or accelerate the activation of $\mathrm{C}-\mathrm{H}$ bonds in methanol, which is not difficult to understand. In fact, this behavior is consistent with the previous literature on $\mathrm{C}-\mathrm{H}$ activation in Ir compounds ${ }^{38}$ and PtRuRh/C. ${ }^{13}$

In order to clarify the rds of methanol electro-oxidation reaction, we calculated the Tafel slope using the following equation: $\eta=A$ $+b \log i$, where $\eta$ is the overpotential and $b$ is the Tafel slope. The Tafel plots (Fig. 6) for $\mathrm{Pt}_{1} \mathrm{Ru}_{1} \mathrm{Ir}_{1} / \mathrm{C}$ at 25,40 , and $60^{\circ} \mathrm{C}$ have slopes of 127,129 , and $166 \mathrm{mV} \mathrm{dec}{ }^{-1}$, respectively. From the kinetic theory of electrode reaction, a Tafel slope of $118 \mathrm{mV} \mathrm{dec}^{-1}$ means that the reaction involving the first electron transfer is the rds. ${ }^{39}$ The breaking of one of the $\mathrm{C}-\mathrm{H}$ bonds in the $\mathrm{CH}_{3} \mathrm{OH}$ molecule with the first electron transfer is most likely the rds of methanol electrooxidation (Reaction 2), which is also consistent with a recently reported result. $^{23}$

In view of the high activity of the ternary alloy electrocatalysts, the durability for methanol electro-oxidation of $\mathrm{Pt}_{1} \mathrm{Ru}_{1} \mathrm{Ir}_{2} / \mathrm{C}$ was studied. $\mathrm{A} \mathrm{Pt}_{1} \mathrm{Ru}_{1} / \mathrm{C}$ (PtRu: 45 mass \%) electrocatalyst was used as the control sample. The electrocatalysts were subject to consecutive cycles between $0.05-0.80 \mathrm{~V}$ vs RHE at $50 \mathrm{mV} \mathrm{s}^{-1}$ in $0.5 \mathrm{M} \mathrm{H}_{2} \mathrm{SO}_{4}$ to degrade the catalyst to varying extent. Methanol electro-oxidation was measured by chronoamperometry after the accelerated degradation cycles. The mass activities after the accelerated potential cycling tests are summarized in Table III. In the case of $\mathrm{Pt}_{1} \mathrm{Ru}_{1} \mathrm{Ir}_{2} / \mathrm{C}$, $40 \%$ of the initial mass activity is maintained after 2000 cycles. Under the same experimental conditions, the mass activity for $\mathrm{Pt}_{1} \mathrm{Ru}_{1} / \mathrm{C}$ decreases to $20 \%$ of its initial value. In order to gain information on the basis for the enhanced stability, XPS measurements were conducted after the degradation test and compared with the data of the initial catalysts. The binding energies of Pt $4 \mathrm{f}, \mathrm{Ru}$ $3 \mathrm{p} 3 / 2$, and Ir $4 \mathrm{f}$ do not show any significant change before and after the accelerated durability tests (Fig. 7), suggesting that there is no qualitative difference after durability tests. Figure 8 shows the change in the $\mathrm{Ru} / \mathrm{Pt}$ and $\mathrm{Ir} / \mathrm{Pt}$ ratios from the initial ratios as a function of the number of potential cycles for $\mathrm{Pt}_{1} \mathrm{Ru}_{1} \mathrm{Ir}_{1} / \mathrm{C}$, $\mathrm{Pt}_{1} \mathrm{Ru}_{1} \mathrm{Ir}_{2} / \mathrm{C}$, and $\mathrm{Pt}_{1} \mathrm{Ru}_{1} / \mathrm{C}$ (the initial $\mathrm{Ru} / \mathrm{Pt}$ and $\mathrm{Ir} / \mathrm{Pt}$ ratio is taken as unity for sake of comparison). In the case of $\mathrm{Pt}_{1} \mathrm{Ru}_{1} / \mathrm{C}$, a decrease in the $\mathrm{Ru}$ content is observed, which most likely reflects the dissolution of metal $\mathrm{Ru}$. The degradation rate of $\mathrm{Ru}$ dissolution is evidently suppressed by the addition of Ir. A slight decrease in Ir/Pt ratio was also observed. From these observations, we suggest that 

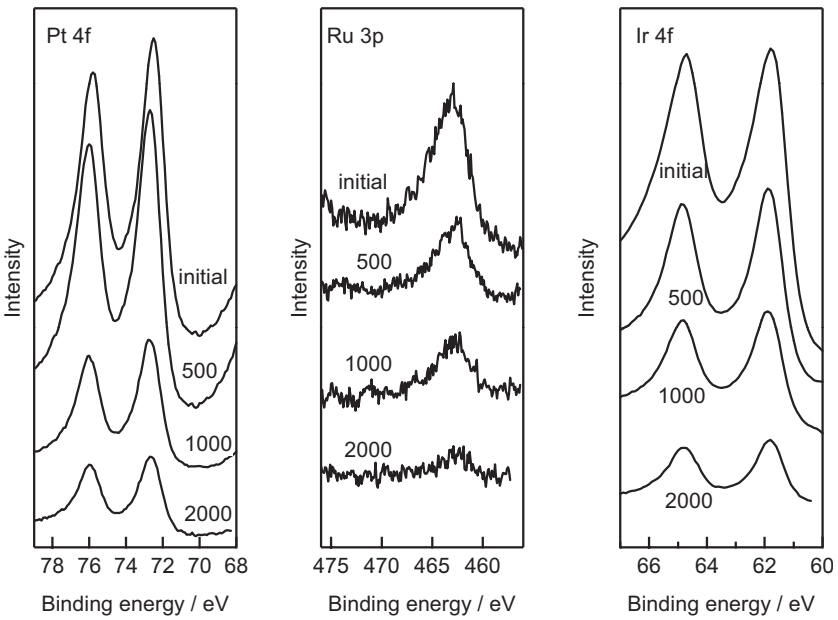

Figure 7. XPS spectra of Pt 4f, Ru 3p, and Ir 4f core-level region before and after the different voltammetry cycles (500, 1000, and 2000 cycles) for $\mathrm{Pt}_{1} \mathrm{Ru}_{1} \mathrm{Ir}_{2} / \mathrm{C}$.

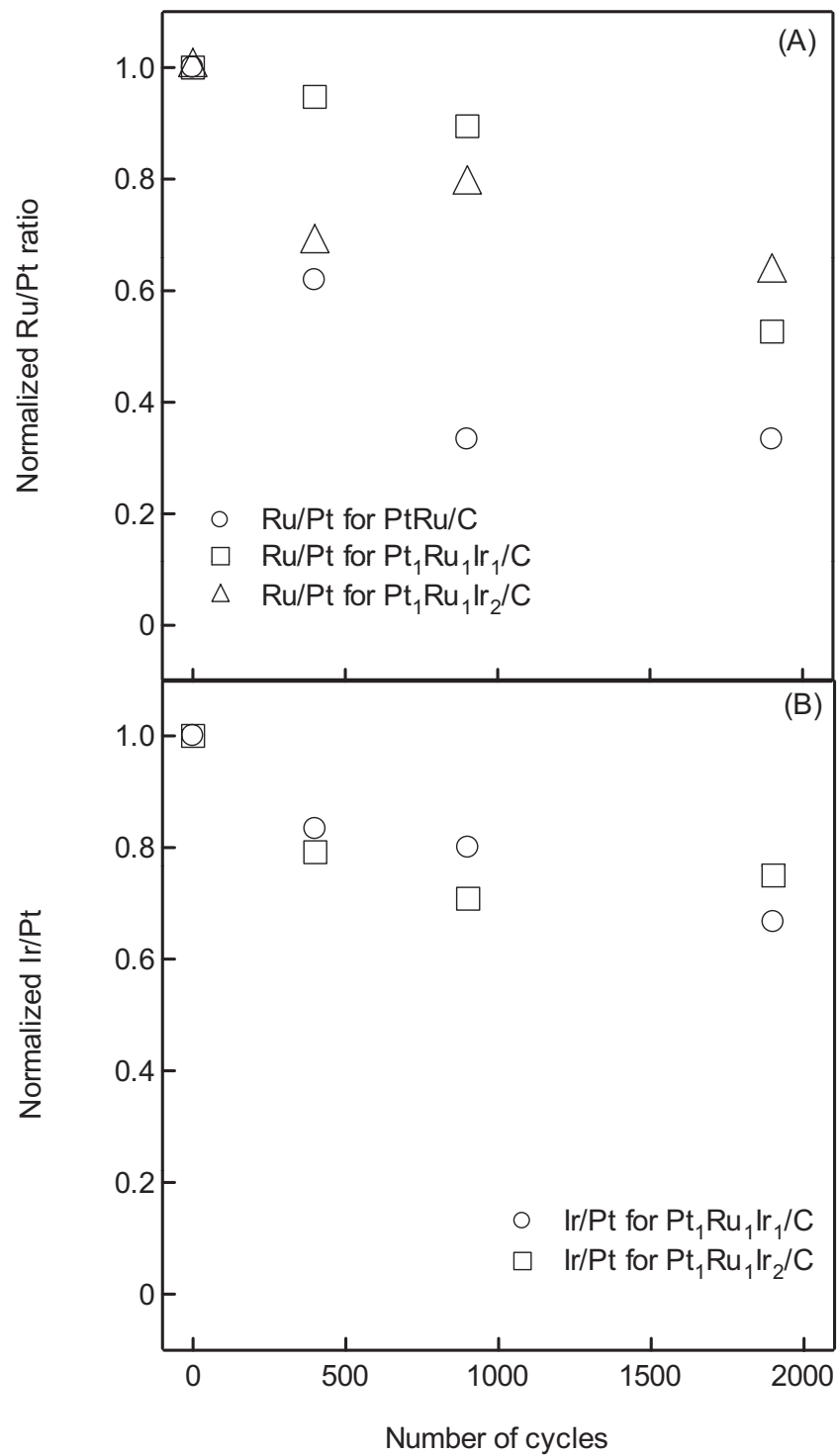

Figure 8. Normalized (A) Ru/Pt and (B) Ir/Pt ratio obtained by XPS as a function of the number of cycles for $\mathrm{Pt}_{1} \mathrm{Ru}_{1} \mathrm{Ir}_{1} / \mathrm{C}$ and $\mathrm{Pt}_{1} \mathrm{Ru}_{1} \mathrm{Ir}_{2} / \mathrm{C}$. the main cause for the degradation of the $\mathrm{Pt}_{1} \mathrm{Ru}_{1} / \mathrm{C}$ catalyst under the present potential cycling procedures is the loss of $\mathrm{Ru}$ from the alloy. The addition of Ir improves the stability of catalyst and reduces the loss of $\mathrm{Ru}$, which should be the main reason for the higher durability of $\mathrm{Pt}_{1} \mathrm{Ru}_{1} \mathrm{Ir}_{x} / \mathrm{C}$ catalysts for methanol electro-oxidation.

\section{Conclusions}

Highly dispersed ternary $\mathrm{Pt}_{1} \mathrm{Ru}_{1} \mathrm{Ir}_{x} / \mathrm{C}$ anode catalysts with $x$ $=0,1 / 2,3 / 4,1,3 / 2$, and 2 for direct methanol fuel cells were prepared. Electrochemical measurements revealed that the methanol electro-oxidation on $\mathrm{Pt}_{1} \mathrm{Ru}_{1} \mathrm{Ir}_{x} / \mathrm{C}$ is strongly dependent on the $\mathrm{Ir}$ content and working temperature. The ternary catalysts exhibited enhanced methanol electro-oxidation activity despite the fact that the $\mathrm{CO}_{\mathrm{ad}}$ oxidation capability was not improved. The Tafel slopes suggest that the role of Ir is most likely to accelerate the elemental steps of the methanol electro-oxidation (i.e., dehydrogenation of methanol). In addition to the increased activity, PtRuIr/C exhibited better durability against consecutive cycling. XPS results suggested that the addition of Ir improves the stability of catalyst by reducing the loss of $\mathrm{Ru}$.

\section{Acknowledgment}

This work was supported in part by the "Polymer Electrolyte Fuel Cell Program" from the New Energy and Industrial Technology Development Organization (NEDO) of Japan, in collaboration with Toray Industries, Inc. ticle.

Shinshu University assisted in meeting the publication costs of this ar-

\section{References}

1. A. S. Aricò, S. Srinivasan, and V. Antonucci, Fuel Cells, 1, 133 (2001).

2. E. Antolini, Mater. Chem. Phys., 78, 563 (2003).

3. J. S. Spendelow, P. K. Babu, and A. Wieckowski, Curr. Opin. Solid State Mater. Sci., 9, 37 (2005).

4. M. Watanabe and S. Motoo, J. Electroanal. Chem. Interfacial Electrochem., 60, 267 (1975).

5. P. K. Babu, H. S. Kim, E. Oldfield, and A. Wieckowski, J. Phys. Chem. B, 107, 7595 (2003).

6. K.-W. Park, J.-H. Choi, B.-K. Kwon, S.-A. Lee, Y.-E. Sung, H.-Y. Ha, S.-A. Hong, H. Kim, and A. Wieckowski, J. Phys. Chem. B, 106, 1869 (2002).

7. M. Krausa and W. Vielstich, J. Electroanal. Chem., 379, 307 (1994).

8. H. A. Gasteiger, N. Marković, P. N. Ross, Jr., and E. J. Cairns, J. Phys. Chem., 97, $12020(1993)$

9. E. Ticanelli, J. G. Beery, M. T. Paffett, and S. Gottesfeld, J. Electroanal. Chem Interfacial Electrochem., 258, 61 (1989).

10. M. T. M. Koper, J. J. Lukkien, A. P. J. Jansen, and R. A. van Santen, J. Phys. Chem. B, 103, 5522 (1999).

11. T. E. Shubina and M. T. M. Koper, Electrochim. Acta, 47, 3621 (2002).

12. E. Antolini, Appl. Catal., B, 74, 324 (2007).

13. T. Kawaguchi, Y. Rachi, W. Sugimoto, Y. Murakami, and Y. Takasu, J. Appl. Electrochem., 36, 1117 (2006).

14. F. Liu, J. Y. Lee, and W. J. Zhou, Small, 2, 121 (2006).

15. W. C. Choi, J. D. Kim, and S. I. Woo, Catal. Today, 74, 235 (2002).

16. M. Götz and H. Wendt, Electrochim. Acta, 43, 3637 (1998).

17. P. Strasser, Q. Fan, M. Devenney, W. H. Weinberg, P. Liu, and J. K. Nørskov, J. Phys. Chem. B, 107, 11013 (2003).

18. T. Kawaguchi, D. Matsuki, M. Dohi, W. Sugimoto, Y. Murakami, and Y. Takasu, Abstract 40, The Electrochemical Society Meeting Abstracts, Vol. 2005-2, Los Angeles, CA, Oct 16-21, 2005 .

19. Y. Liang, H. Zhang, H. Zhong, X. Zhu, Z. Tian, D. Xu, and B. Yi, J. Catal., 238, 468 (2006)

20. S. Liao, K.-A. Holmes, H. Tsaprailis, and V. I. Birss, J. Am. Chem. Soc., 128, 3504 (2006).

21. P. Sivakumar and V. Tricoli, Electrochem. Solid-State Lett., 9, A167 (2006).

22. D. Geng and G. Lu, J. Phys. Chem. C, 111, 11897 (2007).

23. K. I. B. Eguiluz, G. R. Salazar-Banda, D. Miwa, S. A. S. Machado, and L. A. Avaca, J. Power Sources, 179, 42 (2008).

24. E. Reddington, A. Sapienza, B. Gurau, R. Viswanathan, S. Sarangapani, E. S. Smotkin, and T. E. Mallouk, Science, 280, 1735 (1998).

25. B. Gurau, R. Viswanathan, R. Liu, T. J. Lafrenz, K. L. Ley, E. S. Smotkin, E Reddington, A. Sapienza, B. C. Chan, T. E. Mallouk, and S. Sarangapani, J. Phys. Chem. B, 102, 9997 (1998).

26. T. Kawaguchi, W. Sugimoto, Y. Murakami, and Y. Takasu, J. Catal., 229, 176 (2005)

27. W. Sugimoto, K. Aoyama, T. Kawaguchi, Y. Murakami, and Y. Takasu, J. Elec troanal. Chem., 576, 215 (2005).

28. H. Gasteiger, N. Markovic, P. N. Ross, Jr., and E. Cairns, J. Electrochem. Soc. 141, 1795 (1994). 
29. S. N. Tripathi and M. S. Chandrasekharaiah, J. Less-Common Met., 91, 251 (1983).

30. H. A. Gasteiger, P. N. Ross, Jr., and E. J. Cairns, Surf. Sci., 293, 67 (1993).

31. Y. Takasu, H. Itaya, T. Iwazaki, R. Miyoshi, T. Ohnuma, W. Sugimoto, and Y. Murakami, Chem. Commun. (Cambridge), 2001, 314 (2001).

32. T. Frelink, W. Vissche, and J. A. R. van Veen, Surf. Sci., 335, 353 (1995).

33. A. E. Shilov and G. B. Shul'pin, Chem. Rev. (Washington, D.C.), 97, 2879 (1997).

34. J. Greeley and M. Mavrikakis, J. Am. Chem. Soc., 126, 3910 (2004).
35. J. Jiang and A. Kucernak, J. Electroanal. Chem., 533, 153 (2002).

36. S. K. Desai, M. Neurock, and K. Kourtakis, J. Phys. Chem. B, 106, 2559 (2002).

37. K. Franaszczuk, E. Herrero, P. Zelenay, A. Wieckowski, J. Wang, and R. I. Masel, J. Phys. Chem., 96, 8509 (1992).

38. A. A. Bengali, B. A. Arndtsen, P. M. Burger, R. H. Schultz, B. H. Weiller, K. R. Kyle, C. B. Moore, and R. G. Bergman, Pure Appl. Chem., 67, 281 (1995).

39. N. A. Tapan and J. Prakash, Turk. J. Eng. Environ. Sci., 29, 95 (2005). 